\title{
透過式眼鏡型視線検出システムの実用化に向けた人的要因の検討
}

\section{Human Factors for Practical Use of Wearable Line-of-Sight Detection System}

\author{
○学 小川実穗（慶大）学 小澤 真昂（慶大）学 三幣 康太（慶大） \\ Carlos Cotes（慶大） 正 三木 則尚（慶大, JST PRESTO）
}

\begin{abstract}
Miho Ogawa , Keio University, 3-14-1 Hiyoshi Kohoku-ku Yokohama Kanagawa Japan Masataka Ozawa , Keio University, 3-14-1 Hiyoshi Kohoku-ku Yokohama Kanagawa Japan Kota Sampei , Keio University, 3-14-1 Hiyoshi Kohoku-ku Yokohama Kanagawa Japan Carlos Cotes , Keio University, 3-14-1 Hiyoshi Kohoku-ku Yokohama Kanagawa Japan Norihisa Miki , Keio University, 3-14-1 Hiyoshi Kohoku-ku Yokohama Kanagawa Japan
\end{abstract}

The line-of-sight detection system has promising applications in various fields, such as human-computer interaction and marketing. In our previous work, we proposed wearable line-of-sight detection system using micro-fabricated transparent optical sensor on eyeglass and successfully demonstrated line-of-sight detection using the proposed system. However, it required careful calibration with respect to each user and line-of-sight detection even failed for some subjects. We consider that characteristics of the subjects that include shapes of eyes, heights of noses, etc. are the crucial parameters. We investigated which factors are dominant on the reaction rate and the reaction speed of the cells to achieve a practical use.

Key Words: Line-of-sight detection system, Dye-sensitized solar cell, Information communication technology

\section{1. 序論}

視線検出技術は，視線追跡を利用したヒューマンインタ フェースやマーケティングツールなど幅広い分野への応用 が期待されている．現在主流である視線検出システムは, 外 部カメラを用いて眼球運動を撮影し視線を検出する手法で あるが,これらの視線検出システムは被験者の行動範囲の制 限，視野の妨害，常にカメラを向けられることによる精神的 負担といった多くの問題を抱えている.そこで本研究では被 験者の負担を軽減し,より自然な状態での視線検出を可能に すべく，Fig. 1 に示す透過式眼鏡型視線検出システムを提案 している. 本システムは (i )自由な行動が可能，(ii) 視野を 妨げない, (iii)約 $60 \mathrm{~g}$ と従来の物と比べ軽量, という特徵を 持ち, 従来の視線検出システムの問題点を解決するものであ る. 本システムでは光強度に応じた電圧を出力する光センサ をメガネレンズ上に配置し, 白目・黒目の反射光強度が異な る(白目 >黒目) ことを利用し，瞳位置を検出する. 本研究 室では，前述のシステムを用いた視線検出に成功した(1)。し かしながら, 本システムは被験者ごとに詳細なキャリブレー ションが必要であるという問題や，また被験者によっては視 線検出そのものが困難であるという問題を抱えていた.これ は，被験者によって眼の大きさや，鼻の高さが異なるため， 眼鏡をかけた際にセンサ位置が被験者毎に異なることに起 因すると考えられる. 本論文では, 今後の本システムを用い たアプリケーション開発に向けて, 被験者毎の顔形状や眼球 の違いが及ぼす素子反応率や反応速度への影響について述 べる.

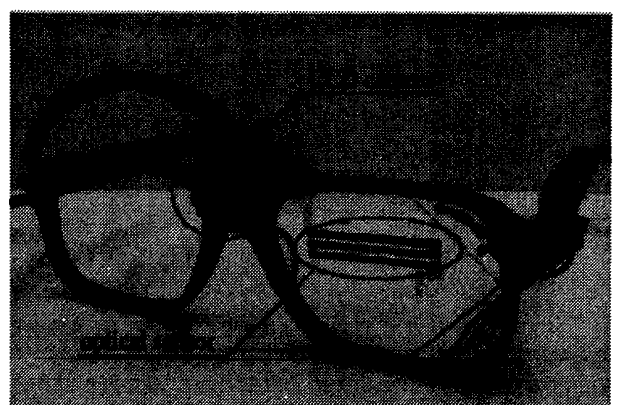

Fig. 1 Wearable line-of-sight detection system using micro-fabricated transparent optical sensors on eyeglasses.
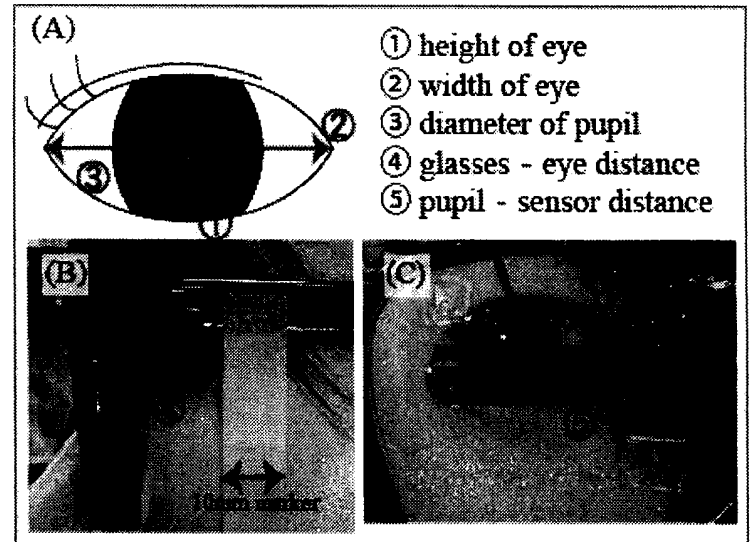

Fig. 2 Points which were measured around eye.

\section{2. 被験者別反応率・反応速度測定実験}

15 名の被験者に対し, 眼球周りの顔形状の測定およびセン サ反応率・反応速度の測定を行い，これらのデータを比較す ることで, 顔形状と反応率・反応速度の関係を調べた.

2-1 顔形状測定 各被験者に対し, Fig. 2 に示す様に(1)眼の 高さ(2)眼の幅(3)瞳直径(4)眼鏡 - 眼球間距離(5)瞳中心 - セン サ間距離の 5 つをそれぞれ測定した．被験者の顔に $10 \mathrm{~mm}$ 角のマーカーを張り付け, 本デバイス装着時の写真を撮影し, 画像処理によって測定した.

2-2 反応率・反応速度測定 製作した本システムを用いて, 水平・垂直方向それぞれの視線検出実験を，同一条件下で各 被験者について行った. 実験は, 蛍光灯下で $10 \mathrm{~mm}$ 間隔で 5 点の注視点を描いたホワイトボードを被験者の $1 \mathrm{~m}$ 前方に 用意し, これらの点を被験者が 5 秒ずつ注視することで行っ た. その後, Fig. 3 に示すように, 眼球回転前と回転後の電 圧值の差を反応の大きさとして測定した。この時, 測定開始 時にセンサ中心位置が瞳に対し左右どちらにあるかで, 左方 向を注視した場合と右方向を注視した場合の反応率の大き さが異なると考えられる. その為, 左右両方向の注視に関し てこれらの反応率をセンサ位置に関わらず均一の条件にす る為に, 左方向を注視した場合と右方向を注視した場合の電 圧值の平均を水平方向の反応率とした。 

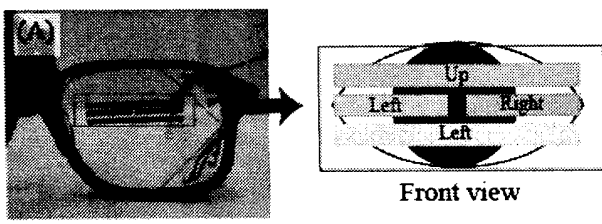

(B)

Front view

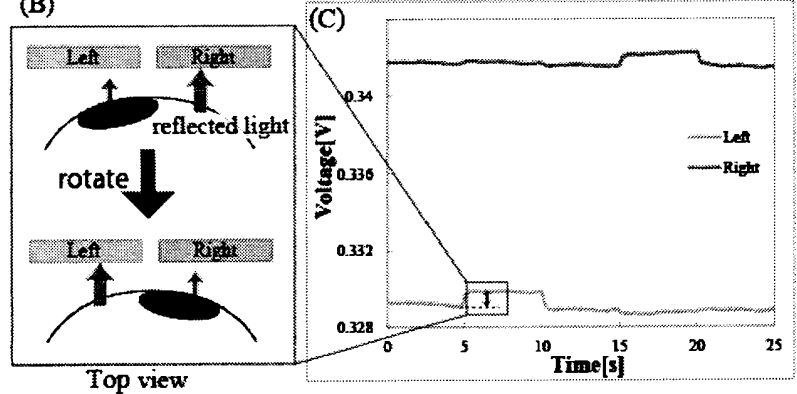

Fig. 3 The algorithm of line-of-sight detection. (A) Arrangement of cells. (B) Way to detect the view angle. (C) Voltage-Time
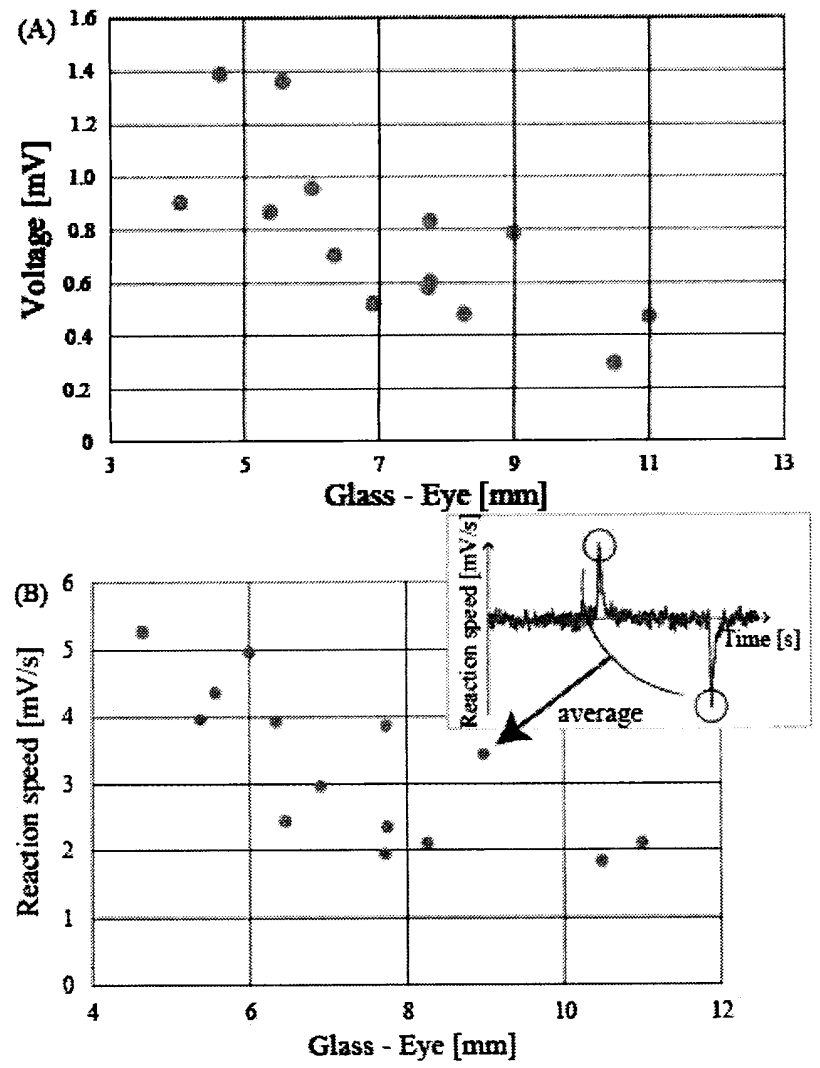

Fig. 4 (A) The relationship between distance of Glass - Eye and voltage. (B) The relationship between distance of Glass - Eye and reaction speed.

\section{3. 結果と考察}

(1)眼の高さ(2)眼の幅(3)瞳直径に関しては反応率・反応速 度共に大きな相関関倸が見られなかった. Fig. 4 に(4)眼鏡 眼球間距離と反応率 . 反応速度との関倸を示寸. 反応速度に 関しては該当素子の反応速度の最大值と最小值の平均をと ることにより求めた. Fig. 4 より, 反応率・反応速度共に(4) 眼鏡 - 眼球間距離と相関関係があり, 眼鏡 - 瞳間距離が小さ くなるにつれて反忘率・反応速度がそれぞれ大きくなること
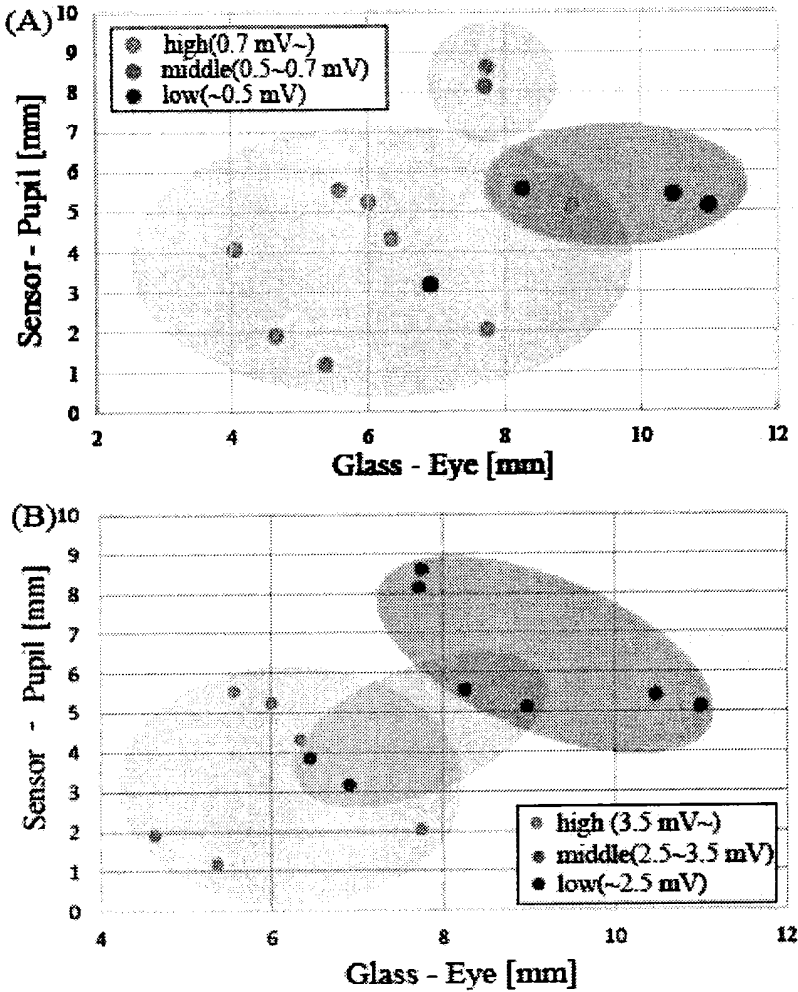

Fig. 5 (A) The reaction volume between the distance of Sensor - Pupil and the distance of Glass - Eye. (B) The reaction speed between the distance of Sensor - Pupil and the distance of Glass - Eye.

が明らかになった。ささらに，他の条件による影響を考察する ため，最も支配的な条件である(4)眼鏡 - 眼球閒距離と，(5)瞳 中心 - センサ間距離を軸にとり, 各被験者の反忍率・反応速 度の振る舞いを調べ色別に分類し, Fig. 5 に示す. Fig. 5 より (4)眼鏡 - 眼球間距離が等しい場合においても，(5)瞳中心 - セ ンサ閒距離が大きくなることで反応率・反応速度は小さくな り，(5)瞳中心 - センサ間距離が反応の大きさに影響を及ぼし ていることがわかった。

\section{4. 結論および今後の展望}

本システムは眼鏡 - 瞳間距離を小さくすることで, 測定に 適する反応が得られることがわかった，さらに，瞳中心－セ ンサ中心間距離がセンサの反応に影響を与えることがわ かった，今後はレンズを可動式にし，眼鏡 - 瞳間距離や，瞳 中心 - センサ中心間距離の調整が可能な眼鏡フレームの開 発を行い,より多くの被験者に適用できるシステムを構筑す ることを目指す。

\section{謝辞}

本研究は JST PRESTO(情報環境と人)の助成を受けたもので ある。

\section{引用文献}

(1)Ozawa Masataka, Design of micro-fabricated transparent optical sensors for accurate line-of-sight detection and their applications in information communication technology, Transducers 2013 Barcelona SPAIN, 16-20 June 2013, 1497-1498 